\title{
Making a definite be interpreted as an indefinite
}

\author{
URTZI ETXEBERRIA
}

\begin{abstract}
This paper proposes a novel analysis for the Basque definite determiner [-a] where it is argued, in opposition to other scholars (cf. Artiagoitia, 2002, 2006 where [-a] is argued to be a number marker when it gets the existential narrow scope interpretation), that the Basque definite determiner (despite its various interpretations) is just that, a definite determiner. Moreover, based on the behaviour of this element, this paper provides extra evidence in favour of the Neocarlsonian approach (cf. Chierchia, 1998b; Dayal, 2004) where the existential interpretation of bare nouns $(B N)$ is shown to be dependent on the kind-level reading. This evidence should also be taken as proof against the so-called Ambiguity analysis (cf. Diesing, 1992; Kratzer, 1995; a.o.) or the Property-based approach to BNs, (cf. McNally, 1995; Laca, 1996; Dobrovie-Sorin \& Laca, 2003) where BNs' existential interpretation is argued to be non-dependent on any other reading. Furthermore, observing the different interpretations that the definite determiner can force in Basque - referential, kind, and existential -, this language is shown to be typologically in between English and French (as argued by Etxeberria, 2005).
\end{abstract}

\section{Introduction}

In Basque linguistics, determination has become a classical discussion topic. What make this topic interesting are the various functions the Basque definite article (D) can accomplish. These various functions can be observed in two

\footnotetext{
* The research conducing to this paper has benefited from the Basque Government projects GIC07/144-IT-210-07 and Hm-2008-1-10, from the project FR2559 Fèderation Typologie et Universaux Linguistiques, from the project TSABL (ANR-07-CORP-033) from ANR as well as from the project FFI2008-00240 from MCE. I'm very grateful to Roberta Pires de Oliveira and Carmen Dobrovie-Sorin for inviting me to write this paper and for their patience. Usual disclaimers apply.
} 
contexts: (i) its syntactic distribution, (ii) the possible interpretations that it can force.

Observing the syntactic distribution of the Basque D, it is important to note that the Basque D must necessarily appear with all the arguments if the sentence is going to be grammatical. ${ }^{1}$ However, this is not the only use of [-a], since it can also appear with predicates; in those cases it plays the role of the participle or of individual-level predication. This use of the D will not be considered in this paper (cf. Zabala, 1993, 2003; Artiagoitia, 1997; Eguren 2006, to appear; Matushansky, 2005; Etxeberria, in prep; for possible analyses) and we will only concentrate on its use on argumental position. The presence of the Basque D is also necessary with strong quantifiers (cf. Milsark 1977) where it has been argued to be contextually restricting the quantificational domain in the overt syntax (cf. Etxeberria, 2005, 2008, 2009; Etxeberria \& Giannakidou, 2009).

With respect to the interpretations that the Basque D can force, it normally marks definiteness (both extensional and intensional), but it can also force the so-called existential interpretation (with obligatory narrow scope) when combined with plurals or mass terms (cf. Artiagoitia, 2001, 2002, 2006; Etxeberria, 2005, in prep). ${ }^{2}$

In this paper, I first present the use and behaviour of the Basque D to then propose a novel analysis of it where I argue, in opposition to other scholars (cf. Artiagoitia, 2002 and references therein), that the Basque D (despite its

${ }^{1}$ The presence of an indefinite determiner (ia) or a weak quantifier (ib) (cf. Etxeberria, 2005, 2008, in prep) also makes the sentence grammatical.

(i) a. Mutil bat berandu iritsi zen.

boy one late arrive aux.past

'A boy arrived late'

b. Mutil asko berandu iritsi ziren

Boymany late arrive aux.past

'Many boys arrived late'

Since we will concentrate on the Basque article in this paper, what I'm saying is the following: Basque does not accept BNs in argument position. Note however that this statement is not completely correct; in the Basque dialect from Zuberoa (most eastern Basque dialect) BNs can appear in object position (only).

(ii) a. Bortüan ikusi dut behi, ardi eta mando (Coyos, 1999: 232) mountain.D-in see aux cow sheep and mule 'I've seen cows, sheeps, and mules in the mountain'

b. Sagar ebatsi dü (Manterola, 2006) apple steal aux 'S/he has stolen money'

This paper will not consider this usage and will assume that the absence of the D makes the sentence ungrammatical; cf. Etxeberria (in prep) for a possible analysis. Thanks to Maider Bedaxagar and Battittu Coyos for help with the Basque from Zuberoa.

2 The existential reading could also be called indefinite; however, there are some important differences between the existential reading that the Basque D (or BNs in English or Spanish) can obtain and the existential interpretation that real indefinites (e.g. a) get. This could also be applied to the title. Cf. footnote 14 . 
various interpretations) is just that, a definite D. Moreover, this paper provides evidence in favour of the Neocarlsonian (NC) analysis and the Derived Kind Predication proposed in it -cf.§3.2.- (Chierchia, 1998; Dayal, 2004; Zamparelli, 2002a), where BNs, in their way to the existential reading, need to get the kind reading first. At the same time, this should be taken as evidence against the Ambiguity approach (Wilkinson, 1991; Diesing, 1992; Kratzer, 1995; a.o.) as well as the Property-based approach to BNs (McNally, 1995; Laca, 1996; Dobrovie-Sorin \& Laca, 2003; a.o.). ${ }^{3}$ Finally, Basque will be shown to be typologically in between English and French.

\section{The Basque definite article: its use and possible interpretations}

The Basque D is a bound morpheme that takes the phonetic forms [-a] (when singular) and [-ak] (when plural). ${ }^{4}$

(1) a. gizon-a

Man-D.sg

'the man'

b. gizon-ak

man-D.pl

'the men'

One very interesting property of Basque is that BNs cannot appear as arguments and the overt presence of the Basque D is obligatory for sentences to be grammatical (cf. footnote 1), as the examples in (1) show (cf. Laka, 1993; Artiagoitia, 1997, 1998, 2002; among others). ${ }^{5}$

Subject position:

(2) a. Irakasle*(-a) berandu etorri zen teacher-D.sg late come aux 'The teacher came late'

b. Irakasle*(-ak) berandu etorri ziren teacher-D.pl late come aux 'The teachers came late'

\footnotetext{
${ }^{3}$ The property-based approach will not be considered in this paper. For some problems that this analysis would have to face, the reader is referred to Chierchia (1998).

${ }^{4}$ Some authors argue that the plural form of the Basque D [-ak] is a single element (cf. Goenaga, 1978, 1991; Euskaltzaindia, 1993; Artiagoitia, 1997, 1998, 2002, 2003, 2004; Rodriguez, 2003; Trask, 2003). Based on Etxeberria (2005), I defend that singular and plural markers and $\mathrm{D}$ are base-generated in different syntactic positions; see also Eguren, 2006; see \$3.2.1. However, for ease of exposition, I will refer to $[-\mathrm{a}]$ and $[-\mathrm{ak}]$ as the singular and the plural D respectively.

5 The absolutive marker is $\varnothing$.
} 
Object position:

(3) a. Martxelek pilot*(-a) hartu zuen Martxel.erg ball-D.sg take aux

'Martxel took the ball'

b. Martxelek pilot*(-ak) hartu zituen

Martxel.erg ball-D.pl take aux

'Martxel took (the) balls'

If BNs cannot appear in argument position in Basque, the question that could come to our mind is how Basque will be able to express what other languages express by means of BNs. For example, English and other Germanic languages can use bare plurals and mass terms without $\mathrm{D}$ to express both the kind reading (4) as well as the existential reading (5).

(4) a. Fishes appeared 390 million years ago

b. Silver has the atomic number 47

(5) a. Garazi has eaten olives

b. Moles are ruining our garden

As soon as we approach the phenomenon, we notice that the Basque D is of broader use than the D of languages like English or Romance languages: In addition to the usual referential interpretation that we get both in (2) and (3) it also appears in contexts where other languages typically present BNs, e.g. Spanish or English -not French, where BNs are not accepted but in coordination contexts; cf. Roodenberg, 2004-. To begin with, just as in Romance languages, when the Basque $[\mathrm{NP}+\mathrm{D}]$ sequence combines with kind level predicates (e.g. evolve, become extinct, be common, etc.; cf. Carlson, 1977; cf. also Krifka et al., 1995), the usual specific interpretation (i.e. the definite extensional interpretation) disappears and it adopts a kind reading where the DP makes reference to the species as a whole (creating an intesional interpretation, which makes reference to the biggest plurality of the set denoted by the NP in all possible worlds and situations). ${ }^{6}$

(6) a. Dinosauru-ak aspaldi desagertu ziren dinosaur-D.pl long time ago disappear aux 'Dinosaurs disappeared a long time ago'

b. Nitrogeno-a ugaria da gure unibertsoan nitrogen-D.sg abundant is our universe.in 'Nitrogen is abundant in our universe'

\footnotetext{
${ }^{6}$ Romance languages make use of the D to express kinds. I exemplify with Spanish.

(i) [Los peces] aparecieron hace 390 millones de años. [the fishes] appeared ago 390 millions of years
} 
In the examples in (6), the DPs dinosauruak 'dinosaurs' and nitrogenoa 'nitrogen' do not make reference to a specific set of dinosaurs or to a specific quantity of nitrogen, but to the species dinosaurs and to the species nitrogen.

Now, when Basque definite DPs (plurals and masses) fill the direct object slot, the definite DP can but need not make reference to a specific set and can obtain the so-called existential interpretation (7). In other words, in the examples in (7) we need not be talking about a specific set of candies or a specific quantity of wine. ${ }^{7}$

(7) a. Amaiak goxoki-ak jan ditu Amaia.erg candy-D.pl.abs eat aux 'Amaia has eaten (the) candies'
b. Izarok ardo-a edan du
Izaro.erg wine-D.sg.abs drink aux 'Izaro has drunk (the) wine'

Note that in the examples in (7) the object DPs cannot make reference to the whole species denoted by the NP. However, a specific interpretation is possible for both the object DP in (7); that is, if we were to offer English translations (7a) and (7b) would be ambiguous: (7a) 'Amaia has eaten the candies' or 'Amaia has eaten candies'; (7b) 'Izaro has drunk the wine' or 'Izaro has drink wine'.

Some singular definite DPs can also get the so-called existential reading as shown by the example in (8). This paper will not try to provide an account for this use; cf. Rodriguez (2003), Etxeberria (2005, in prep) or Eguren (2006) for a possible analysis; cf. Manterola (2006) for a dyachronic analysis.
(8) Jonek auto-a erosi zuen. Jon.erg car-D.sg.abs buy aux 'Jon bought (the/a) car'

This sentence is also ambiguous: in one of the readings Jon has bought a specific car, e.g. the one that he mentioned he was going to buy: a Citroën

\footnotetext{
${ }^{7}$ Romance languages make use of different strategies to obtain this existential interpretation. Both Spanish and Italian are able to use BNs (just like English or other Germanic languages). On the other hand, French makes use of the so-called partitive determiner des/du and no BNs are allowed (Italian also has a partitive determiner). See Chierchia (1998b), Zamparelli (2000, 2002a, 2002b), Kleiber (1990), Bosveld-de Smet (1997), Heyd (2003), Bosque (1996), Laca (1996). Cf $\S 4.2 .2$ for an analysis where the existential interpretation of English BNs, French partitives and Basque definites (with the definite D) is explained in a unified manner following the Neocarlsonian approach.
Juan has drunk [coffee] Pierre has eaten [of-the sweets]
'Juan has drunk coffee'
'Pierre has eaten sweets.'

Sp.: Juan ha bebido [café]. Fr.: Pierre a mangé [des sucreries].
} 
$2 \mathrm{CV}$; in the other reading the sentence in (8) is taken to be more or less parallel to something like 'Jon has bough a car' where we don't know which car we are talking about, hence parallel to the non-specific reading of $a$ car.

However, the sequence [count $\mathrm{N}+$ singular D] in (8) can only be interpreted existentially in very specific contexts: so-called stereotypical contexts which are clearly related to possession. All the examples in (9) have a clear sense of possession, that is, once you buy a car/house, you become the possessor, having something is also closely related to possession, as it is wearing something (e.g. hat). It is obvious then that singular definite DPs in Basque do not get the existential interpretation as easily as plurals or mass terms do.

(9) a. auto-a/etxe-a erosi

car-D.sg/house-D.sg buy

b. senarr-a/emazte-a eduki

husband-D.sg/wife.D.sg have

c. txapel-a eraman

hat-D.sg bring

Romance languages (at least Spanish, French and Romanian), in order to express what the examples in (9) express, makes use of singular BNs (cf. Bosque 1996 for an extensive presentation of Spanish data; cf. Dobrovie-Sorin, Bleam \& Espinal, 2005; Espinal \& McNally, 2007 for possible analysis). I provide Spanish examples.

(10) comprar coche/casa, tener marido/mujer, llevar sombrero, etc. Buy car/house have husband/wife bring hat

Note that normally Basque [count $\mathrm{N}+$ singular D] sequences that appear in object position of object-level predicates can only get specific interpretations, in contrast with what happens in the examples in (9). In other words, in the examples in (11), we are necessarily talking about a specific book, a specific boy, and a specific magazine, respectively; there is no way we can get a existential reading in the examples in (11):

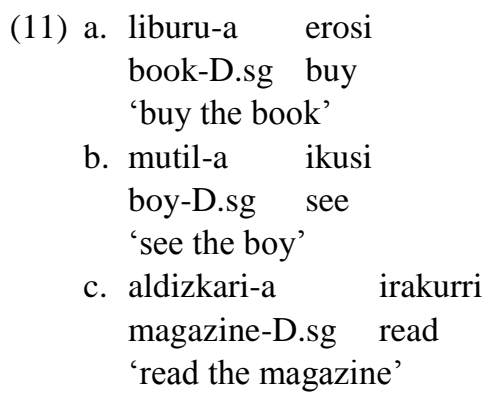


Up until now, we have presented what the use of the Basque definite D is. Once we have seen that Basque must make use of DPs with D in places where other languages use BNs, the next section presents the two main approaches that have tried to account for the different readings that English and Romance languages' BNs can get (cf. fn. 3). Once this is done, the next step will be to check which of these two approaches is able to explain Basque facts best.

\section{Approaches to BNs' readings}

\subsection{The ambiguity analysis}

In the Ambiguity Approach to BNs, kinds do not play a big role and BNs are defended to be systematically ambiguous: in some contexts they refer to kinds, in others they behave as weak indefinites (see Wilkinson, 1991; Diesing, 1992; Gerstner \& Krifka, 1993)

The kind denotation will be the one used in sentences where the predicates are kind-level, as that in (12a) which would have the logical form in (12b).

(12) a. Fishes appeared 390 million years ago.

b. appear 390 million years ago $\left(\right.$ fish $_{\mathrm{k}}$ )

In characterizing sentences such as the one in (13a) on the other hand, BNs behave like weak indefinites, which are bound by an unselective generic operator (Gn). Assuming a tripartite structure for quantification [Q [Restriction] [Nuclear Scope]] (see Lewis, 1975; Kamp, 1981; Heim, 1982), the generically interpreted dogs in (13a) will appear in the restrictive clause as shown in (13b).

(13) a. Dogs bark at the moon.

b. $G n x[\operatorname{dogs}(x)][b a r k$ at the moon $(x)]$

The existential interpretation also comes from the indefinite interpretation of BNs. In this case, BNs appear in the nuclear scope of the quantifier and the free variable the indefinite introduces is bound by an existential quantifier introduced by existential closure as shown in (14b) (cf. Heim, 1982; Diesing, 1992; Kratzer, 1995).

(14) a. Cats are playing with the ball.

b. $\exists x[\operatorname{cats}(x) \&$ playing with the ball(x)]

\subsection{The Neocarlsonian approach}

In this approach, BNs are considered proper names of kinds of things in kind-level contexts (Carlson, 1977; Chierchia, 1998b; Dayal, 2004). Mass 
terms are described as kind denoting elements of type $e$ and can combine directly with the kind-level predicate.

(15) a. Nitrogen is abundant in our universe.

b. abundant in our universe (nitrogen)

Bare Plurals (BP) on the other hand, start life as type $\langle e, t\rangle$ and in order to become arguments of kind predicates are turned into type $e$ via a nominalization operation (nom), described in (17) (expressed as ' $\cap$ ' in 16b). Hence, the logical form of a sentence such as (16a) will be the one in (16b).

(16) a. Fishes appeared 390 million years ago.

b. appeared 390 million years ago ( $\cap$ fishes)

(17) $\operatorname{nom}(\cap):\langle e, t\rangle \rightarrow e: \lambda P\langle e, t\rangle \lambda s i x[P s(x)]$

Now, in object level contexts such as the one in (18), predicates do not apply to kinds, but to non-kind objects.

(18) Cats are playing with the ball.

As a consequence, further operations are needed to repair the type mismatch. This repair involves the introduction of a (local) existential quantifier over the instantiations of the kind. Thus, the BNs are turned into indefinites providing a free variable by the type shifting operation pred (the inverse of nom) that applies anytime the predicate requires an object-level argument. ${ }^{8}$ At the same time, this type shifting operation inserts the existential quantifier. This general mechanism is called 'Derived Kind Predication' (DKP).

(19) Derived Kind Predication (Chierchia 1998b: 364):

If $\mathrm{P}$ applies to objects and $\mathrm{k}$ denotes a kind, then

$\mathrm{P}(\mathrm{k}) \Leftrightarrow \exists \mathrm{x}[\cup \mathrm{k}(\mathrm{x}) \wedge \mathrm{P}(\mathrm{x})]$

$\checkmark \cup$, is a type shifter from kinds to corresponding properties (Pred).

(18') Cats are playing with the ball.

Playing with the ball ( $\cap$ cats)

$\Leftrightarrow \exists \mathrm{x}[\cup \cap$ cats $(\mathrm{x}) \wedge$ playing with the ball(x)] (via DKP)

In characterizing sentences, there is again a type mismatch since the predicate does not accept kinds and the $\mathrm{BN}$ denotes one. Again, the

\footnotetext{
${ }^{8}$ Pred: $e$ (kind) $\rightarrow\langle\mathrm{e}, \mathrm{t}\rangle: \lambda \mathrm{k}_{\langle\mathrm{e}\rangle} \lambda \mathrm{x}[\mathrm{x} \leq \mathrm{k}]$ : It is a function that applies to those entities (kinds) which are entity correlates of properties, and returns the corresponding property.
} 
application of $" \cup$, is needed in order to create an indefinite with a free variable that will be bound by the Gn operator introduced in sentences such as (20a) (see Chierchia, 1995).

(20) a. Dogs bark at the moon.

b. Gnx [ $\sim^{\sim} \operatorname{dogs}(\mathrm{x}) \&$ bark at the moon(x)]

Now that we've seen the two main approaches that have tried to account for the different readings that English BNs can get, in the next section we return to Basque data. I'll first present a previous analysis of the Basque D which will be shown to face some problems; and in the final part, Basque D's behaviour is argued to be analysable in NC terms, and Basque shown to be the 'missing link' between English and French.

\section{Deriving the interpretations of the Basque definite article and its typological nature}

Before moving on to expose the details of the proposal that this paper is going to put forward, I will present the analysis by Artiagoitia (2002) together with some of its problems.

\subsection{An analysis of the Basque D: Artiagoitia (2002)}

Artiagoitia's (2002) analysis is based on Longobardi (1994) where BNs in argument position are argued to be true DPs with an empty D head (despite their determinerless appearance), and as a consequence, (i) are assigned a default existential interpretation and (ii) must be lexically governed at LF. In other words, an empty D head is only possible in internal argument position.

Artiagoitia (2002) applies this proposal to Basque since despite the overt presence of the D (in Basque) the readings are parallel to determinerless DPs of English and Romance languages. Taking this observation seriously, together with the fact that Basque does not mark number on Ns, he concludes that Basque existentially interpreted DPs are structurally similar to determinerless DPs of other languages; and it is the empty D that makes the 'definite' DP be interpreted existentially by default. Therefore, Basque DPs will have two possible structures depending on the interpretation that they will be getting. When the DP is interpreted existentially, the article will just be filling number specification of DPs; with that aim, [-a/-ak] will fill a functional projection between the $\mathrm{D}$ head and the $\mathrm{N}$ head, 'some kind of Number-Phrase, i.e. the noun plus number inflection or the head that Longobardi (2000) simply calls 'H' (Artiagoitia 2002: 84), as in the examples (21a) and (22a). When the DP is interpreted specifically, on the other hand, [-a/-ak] must appear in D position as shown in (21b) and (22b). Singular (Artiagoitia, 2002: 84): 
(21) a.

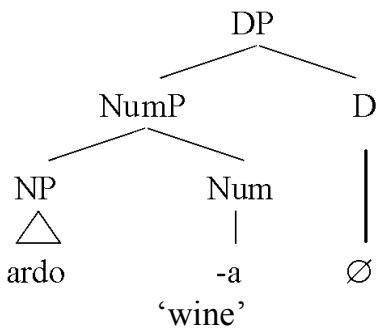

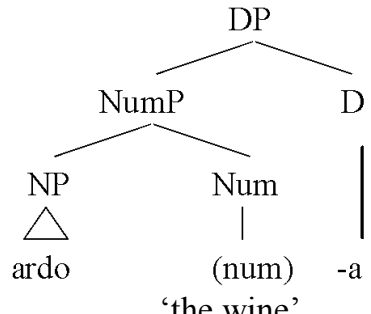

Plural (Artiagoitia, 2002: 84):

(22) a

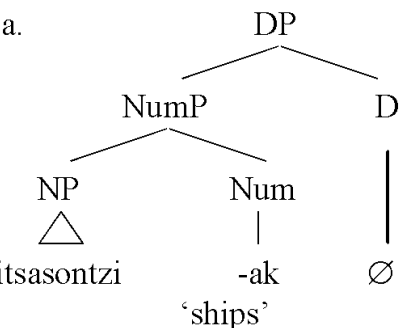

b.

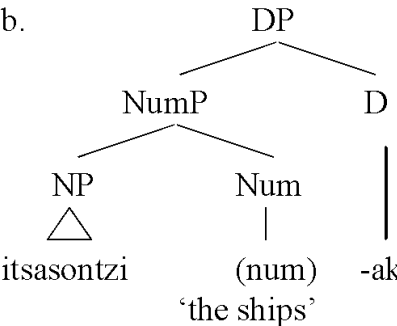

However, this analysis happens to be problematic: Let us build an example with a mass term like garagardo 'beer' (see fn.4) in object position of an object level predicate, as in (23). In this situation, the object DP garagardoa can obtain two interpretations: definite or existential.

(23) Maiak garagardo-a edan zuen.

Maia.erg beer-D.sg.abs drink aux.sg

$\Rightarrow$ Specific: 'Maia drank the beer'

$\Rightarrow$ Existential: 'Maia drank beer'

In the existential interpretation, Artiagoitia does not treat [-a] as a D, rather, the article is placed in [Head, NumP] position and functions as a number marker, a singular number marker (see (21a)). But, do we really want to claim that mass terms denote singulars? Clearly, the answer to this question is negative.

As evidence against Artiagoitia's approach, note that in some contexts (so-called stereotypical contexts; cf. §2), ${ }^{9}$ Basque singular count terms can get an

\footnotetext{
${ }^{9}$ Spanish uses bare singulars (BS) to express these meanings.

(i) Juan ha comprado casa.

Juan has buy house

'Juan bought a house'

Bosque (1996) explains the behaviour of Spanish object BSs by means of a process of incorporation to the verb (head to head movement) and the creation of a complex
} 
existential-like interpretation. A sentence like (24) (copied from example (8)) is ambiguous between a specific and an existential reading.

$$
\begin{aligned}
& \text { (24) Jonek auto-a erosi zuen. } \\
& \text { Jon.erg car-D.sg.abs buy aux } \\
& \Rightarrow \text { Specific: 'Jon bought the car' } \\
& \Rightarrow \text { Existential: 'Jon bought (a) car' }
\end{aligned}
$$

Then, autoa can have an existential-like interpretation in (24); but even in this reading, there is a clear difference between the sentence in (24) and the one in (23). Although both DP objects are claimed to get existential interpretation and (following Artiagoitia) the Basque D [-a] should accordingly be in NumP in both DPs, there is no way in which the sentence in (24) can be interpreted as Jon having bought more than one car, that is, the number of cars is strictly limited to 'one'. This is not the case in (23), where as we said, we don't care about the quantity of beer Maia drank. Thus, the questions to answer are: Why should there be such a difference among the behaviour of the singular (if singular) object DPs in the examples in (23) and (24)? And where does this difference come from?

The next sections provide an answer to these two questions by proposing a novel syntactic and semantic analysis for the Basque D; it is argued that mass terms, in opposition to count terms, are unmarked for number. Furthermore, Basque $\mathrm{D}$ is argued to always be a $\mathrm{D}$, but very flexible in its ability to type-shift, a property that allows us to account for the various interpretations that it forces.

\subsection{Towards a new analysis}

\subsubsection{Syntactic analysis of the Basque D}

What this paper proposes is that mass terms are not number marked, and although they share the property of triggering singular verb agreement with singular count terms, they differ in being number neutral (see Delfitto \& Schroten, 1991; Doetjes, 1997; Dayal, 2004; Krifka, 2004; among many others). Singular agreement with the verb will be just agreement by default. Furthermore, from what we have seen so far masses pattern together with plurals in the interpretations they obtain, that is, semantically, mass terms share more properties with plurals than with real singulars. So despite

predicate. See Dobrovie-Sorin et al. (2006) for a more recent analysis in similar terms.

Rodriguez (2003) assumes Bosque's analysis and tries to apply it to Basque. The only difference is that in Basque the incorporation process would have to take place at LF since the presence of the D (in (24)) blocks the (needed head to head) movement at SS. However, I do not see the way to avoid the SS blockage at LF, since at LF the D will still be present; unless the Basque D is taken to be an expletive. 
agreement facts with verbs, masses are closer in behaviour to plurals than to singulars (see Link, 1983; Gillon, 1992; Higginbotham, 1994; Chierchia, 1998a, 1998b; Bosveld-de Smet, 1998; Pelletier \& Schubert, 2002).

Thus, count terms will be referred to as (morphologically) singular or plural while mass terms will be argued not to bear number morphology at all. In order to explain this difference between count and mass terms, this paper proposes that the $\mathrm{D}[-\mathrm{a}]$ and the singular $[-\varnothing]$ and the plural $[-\mathrm{k}]$ number markers are base generated in different syntactic position (pace standard assumption; see Etxeberria, 2005). As expressed in the example in (25) the number markers will be assumed to be base generated in NumP while the D [-a] will be argued to always be base generated in head of DP, and be always a D. Note that the singularity of singular count terms is not marked in the overt syntax, but I assume there is an empty number marker $(\varnothing)$ (see Azkarate \& Altuna, 2001: ch.2 and references therein), hence the difference with mass terms. ${ }^{10}$

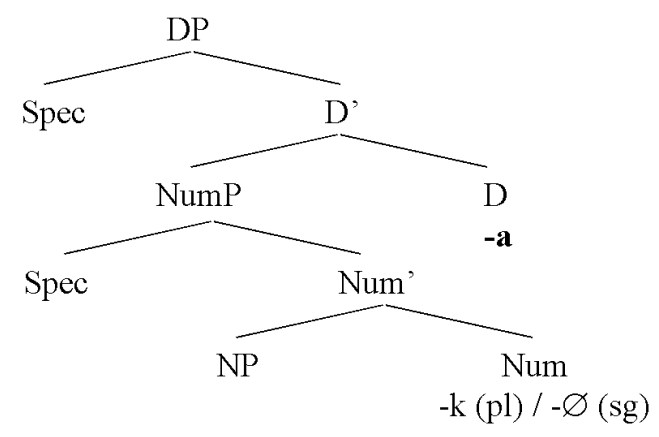

Note that the syntactic structure in (25) does not give us the final surface order of the constituents. In order to do so, the plural marker [-k] (and the empty singular marker $[-\varnothing]$ ) will be considered suffixes, and as such dependent phonologically as well as categorically on another category, ${ }^{11}$ and this category is the $\mathrm{D}$ head. ${ }^{12}$ Therefore, it is possible to postulate that the final

10 This is actually the case with verbal inflectional agreement in Basque. Plural number is marked by suffixation while singular number is unmarked; see Hualde (2003).

Singular

doa 'it/she/he is going' doa-z 'they are going',

dakigu 'we know it' daki-zki-gu 'we know them'

nau 'it/she/he has me' ga-it-u 'it/she/he has us'

11 In opposition to clitics which are only phonologically dependent, cf. Zwicky (1985).

12 Dependent morphosyntactic features are a very common thing across languages; e.g. in Amharic, Case morphology is dependent on the presence of the article (Anderson, 1985). 
movement of the number markers to the final position of the DP is due to morphology (see Etxeberria, 2005; for evidence).

Mass terms on the other hand, being number neutral will need no NumP and will have the structure in (26).

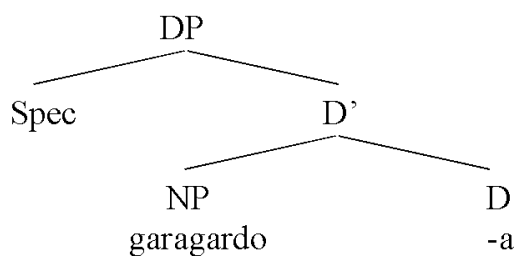

This proposal allows us to answer the questions raised at the end of the previous section: The difference between the sentences in (23) and (24) comes from the fact that Number does in fact play a role; when singular, the interpretation is just singular and this is what the example in (24) shows, which can not be interpreted as Jon having bought more than one car. However, with mass terms, the Basque D does not appear to be imposing any kind of number specifications on the nominal (mass) expression.

A nice consequence of this proposal is the following: the structures in (25-26) make it possible to differentiate count and mass terms avoiding at the same time Artiagoitia's analysis problem, since mass terms are number neutral in my analysis, hence non-singular.

Note also that for Artiagoitia (2002), the plural form of the D [-ak] when existentially interpreted appears in NumP (see 22a). This plurality correctly eliminates the mass interpretation of a nominal expression like garagardo 'beer' in (27). These facts can also be easily accounted for in my proposal, where the plural marker [-k] appears in NumP correctly eliminating the mass denotation of garagardo.

(27) Maiak garagardo-ak edan zituen. Maia.erg beer-D.pl.abs drink aux 'Maia drank different types/sizes of beer.'

However, if following Artiagoitia we would assume that [-a] appears in NumP when (mass terms are) existentially interpreted, this should also eliminate the mass interpretation of garagardo- $a$ 'beer' in (27) -as mass terms are not available when NumP is present-, but clearly it does not. For obvious reasons, these facts are problematic for Artiagoitia; in my analysis on the other hand, [-a] does not fill number specifications of mass nouns and this problem does not arise. 


\subsubsection{Semantic analysis of the Basque $D$}

In this section I show that the NC approach, where the existential interpretation is argued to be dependent on the kind-level interpretation (cf. $\S 3.2$ ), can be applied to Basque data. One of the advantages of my analysis is that $[-\mathrm{a}]$ is treated as a D everywhere; in other words, the Basque $\mathrm{D}$ is given a unified analysis despite its various interpretation that have led other authors to propose that $[-\mathrm{a}]$ forces both a definite and an indefinite (existential) interpretation.

The proposal is that the Basque D allows both the referential and the kind reading (see e.g. Kleiber, 1990; Zamparelli, 2002a; Dobrovie-Sorin, et al., 2006; for Romance). Thus, the Basque D always takes an $\langle e, t\rangle$ element and returns an individual of type $e$; it will play the role of the type-shifter iota when a referential reading is needed, as in the example in (28).

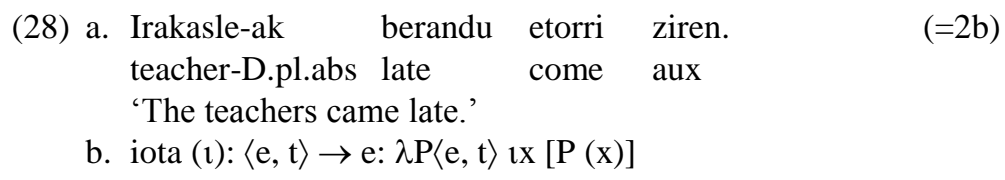

On the other hand, the role of the Basque $\mathrm{D}$ will be that of the type-shifter nom (the intensional version of iota) when the kind reading is needed, i.e., when the DP is combined with kind-level predicates, as in (29).

$$
\begin{aligned}
& \text { (29) a. Dinosauru-ak aspaldi desagertu ziren. (=6a) } \\
& \text { dinosaur-D.pl.abs long time ago disappear aux } \\
& \text { 'Dinosaurs disappeared a long time ago.' } \\
& \text { b. } \operatorname{nom}(\cap):\langle e, t\rangle \rightarrow \text { e: } \lambda P\langle e, t\rangle \lambda s \text { ix }[\text { Ps (x)] }
\end{aligned}
$$

Assuming that the NC approach is correct, in order to obtain the existential reading the definite DP must also be able to have a kind-level meaning, i.e., a necessary step in the way to the existential interpretation is the kind denotation. Thus, as I've shown before, in contexts where the predicate can not apply to kinds, the DKP (see example (19)) is assumed to be needed to repair the type mismatch.

The hypothesis that I develop here is that the DKP allows us to derive some intriguing patterns of cross-linguistic variation with regard to the morphosyntactic make-up of nominals in their existential interpretation. So, Basque is argued to be typologically in between English and French, the difference is that in languages like Basque or French some parts of the derivation of the DKP are overt while some others are kept covert; in English on the other hand, the whole derivation of the DKP is covert (Chierchia, 1998). An extra assumption that I need to make is that French des (de les) / $d u$ (de le) and Basque existentially interpreted $[-\mathrm{a}(\mathrm{k})]$ are built on a kind-denoting definite (cf. Zamparelli, 2002b). 
Thus, as just mentioned, in English the whole derivation of the object ships in (30) will be covert (see §3.2). First, the type-shifter nom creates and individual denoting kind, then the type-shifter pred gives the predicative type back; and finally the existential quantifier quantifies over instantiations of the kind.

(30) Ane has seen [ships].

Existential interpretation: see $(\mathrm{a}, \cap$ ships $) \Leftrightarrow \exists \mathrm{x}\left[{ }^{\cup} \operatorname{ship}(\mathrm{x}) \wedge \operatorname{see}(\mathrm{x})\right]($ via DKP)

Considering that French $d e s / d u$ are composed of the partitive preposition plus the D; in French, part of the derivation of des bateaux in (31) will be overt: nom as well as pred will be overt; the part of the derivation that is covert is the existential quantifier that gives the final existential interpretation.

(31) Ane a vu [des bateaux].

Ane has seen of-the ships

'Ane has seen ships.'

Existential interpretation:

$\operatorname{voir}\left(\mathrm{a}\right.$, les bateaux $\left.\mathrm{b}_{\mathrm{k}}\right) \Leftrightarrow \exists \mathrm{x}[$ de les bateaux $\mathrm{k}(\mathrm{x}) \wedge \operatorname{voir}(\mathrm{x})]($ via DKP)

Finally in Basque, part of the derivation of itsasontziak in (32) will also be overt while part of the derivation will be left covert. First, the D creates an individual kind of type $e$; and although in Basque we only see the $\mathrm{D}$, I assume that there is a covert version of the partitive postposition (similar to French de) that gives us the predicative $\langle\mathrm{e}, \mathrm{t}\rangle$ type back. The role of this covert partitive postposition will be halfway the DKP, that is, it yields an $\langle e, t\rangle$ type element but no existential quantifier. This local existential quantifier will be provided by the DKP which introduces an existential quantification over instantiations of the kind in episodic sentences (an adjustment triggered by the type mismatch).

(32) Anek [itsasontzi-ak] ikusi zituen. Ane.erg ship-D.pl.abs see aux.pl

'Ane saw ships.'

Existential interpretation:

ikusi (a, itsasontziak $\left.\left._{\mathrm{k}}\right) \Leftrightarrow \exists \mathrm{x}\left[\operatorname{itsasontziak}_{\mathrm{k}}(\mathrm{x}) \wedge \operatorname{ikusi}_{\mathrm{x}}\right)\right]($ via DKP)

Note in fact that the behaviour of French $d e s / d u$ is quite similar to the existentially interpreted Basque D. ${ }^{13}$ The difference between the two is that the referential or kind readings available for Basque $\mathrm{D}$ can not be obtained by the French partitive determiners. Thus, in the existential interpretation, they are both (i) rejected as objects of generic sentences (33)-(34); (ii) perfectly

13 All of the French examples in the paper are taken from Bosveld-de Smet (1998). 
acceptable as objects of stage-level predicates (35)-(36); (iii) grammatical also when combined with atelic adverbials (37-38).

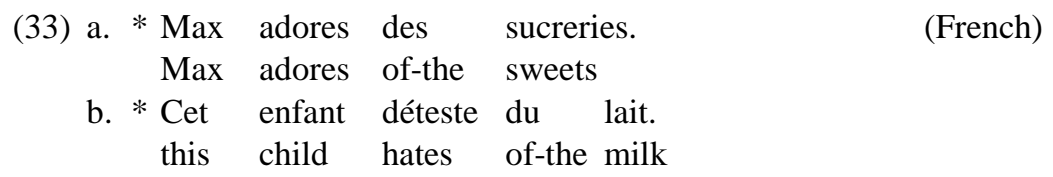

(34) a. Amaiak goxoki-ak maite ditut. Amaia-erg candy-D.pl love aux.pl

(Basque)

'Amaia loves candies'

* Existential interpretation

$\checkmark$ Generic interpretation

b. Ume honek esne-a gorroto du.

child this.erg milk-D.sg hate aux.sg

'This kid hates milk'

* Existential interpretation

$\checkmark$ Generic interpretation

(35) a. J'ai rencontré des amis ce matin. (French) I have met of-the friends this morning

b. Elle a goûte de la bière.

she has drunk of-the beer

(36) a. Italiar lagun-ak topatu ditut gaur goizean. (Basque) Italian friend-D.pl meet aux.pl today morning-in 'I met (the) Italian friends this morning.'

$\sqrt{ }$ Existential interpretation

$\checkmark$ Definite interpretation

b. Anek garagardo-a edan du.

Ane.erg beer-D.sg drink aux.sg

'Ane has drunk (the) beer.'

$\sqrt{ }$ Existential interpretation

$\checkmark$ Definite interpretation

(37) a. Marie a cueilli des fraises pendant des heures.

Marie has picked of-the strawberries for of-the hours

b. * Marie a cueilli des fraises en uneheure.

Marie has picked of-the strawberries inone hour

(38) a. Elenek marrubi-ak jaso ditu ordubetez.

Elene.erg strawberry-D.pl.abs pick aux hour-for

'Elene has picked (the) strawberries for an hour.'

$\sqrt{ }$ Existential interpretation

$\checkmark$ Definite interpretation 
b. Elenek marrubi-ak jaso ditu ordubete batean. Elene.erg strawberry-D.pl.abs pick aux hour one-in 'Miren has picked the strawberries in an hour.'

* Existential interpretation

$\sqrt{ }$ Definite interpretation

Let us now provide some extra evidence supporting the proposal put forward in this section. In the examples in (39), the Basque definite object DP is ambiguous between the definite/referential and the existential interpretation.

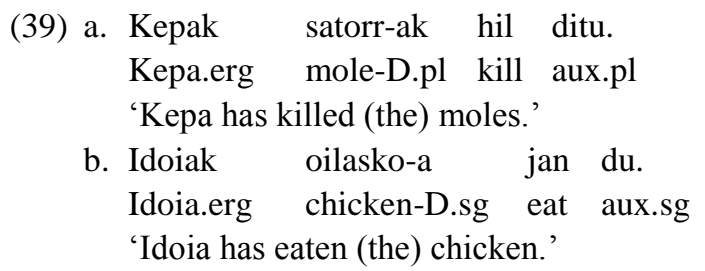

Remember that the NC approach crucially assumes that the existential interpretation exemplified in the previous examples derives from the kind reading. Then, the prediction is that whenever the kind reading is blocked, no existential interpretation will be available anymore. Kinds are assumed to have an intensional component that relates the kind with the intension of that same noun; this intensional component can be blocked by means of a rigid designator in the definite DP as in (40) (see Chierchia, 1998b).

(40) a. Kepak [nere aitaren baratzako satorr-ak] hil ditu. Kepa.erg [my father.gen vegetable garden mole-D.pl] killaux 'Kepa has killed the moles from my father's vegetable garden.'

b. Idoiak [bere amak azokan erositako oilasko-a] jandu. Idota.erg[her mother market-in buy chicken-D.sg]eat aux 'Idoia has eaten the chicken her mother bought at the market.'

The definite expressions in (40a-b) must refer to some contextually unique group of moles, and chicken respectively; that is to say, these definite DPs can only be interpreted referentially, and the existential interpretation is clearly unavailable -as the glosses show-. Furthermore, since the DPs in (40) cannot get the kind reading, the prediction is that when these DPs are combined with kind-level predicates the result will be ungrammatical. The prediction is borne out, as shown in (41).

(41) a. \# [Bizilagunaren etxeko sagu-ak] ohikoak dira hemen. [neighbour.gen house.from mouse-D.pl] typical are here 'The mice from our neighbours' house are common in here.' 
b. \#[Amak azokan erositako oilasko-a] zabalduta dago. [mum.erg market.in buy chicken-D.sg]spread is 'The chicken that my mum bought in the market is widespread.'

The impossibility to obtain kind readings offers clear evidence in favour of the NC approach and against the Ambiguity approach since according to the latter, blocking the kind reading should not block the existential interpretation, but it clearly does as shown in the examples (39-41). ${ }^{14}$ From here, it is possible to conclude that the existential reading is derived from the kind reading and that the $\mathrm{NC}$ approach gets cross-linguistic facts correctly. Thus, the generalization that follows is that Basque definite DPs can only get an existential (indefinite-like) interpretation if and only if they first get a kind-level meaning.

Now, note that the partitive preposition used in constructions such a beaucoup des étudiants 'many of the students' in French is just the same that is used in so-called partitive constructions as des étudiants 'of the students'. Basque makes use of the partitive postposition -tik 'of' in quantificational partitive constructions such as ikasleetatik asko 'lit.: student-D.pl/of many', ${ }^{15}$ and apparently, the role that the pred type-shifter (in DKP) is claimed to play is exactly the same as the one carried out by -tik. In other words, both -tik and pred take an individual of type $e$ and return a set of predicative type $\langle\mathrm{e}, \mathrm{t}\rangle$. Now, assuming that languages with overt type shifters block covert shifts (Chierchia, 1998b), how is it possible to explain that there is in fact a covert type shifter that does exactly the same job an overt partitive preposition (postposition in Basque) does?

Here is how: if we assume (in line with Zamparelli, 2002b) that the French [preposition+D] complex $d e s / d u$ is a structure built on a kind-denoting definite we could argue that the partitive constructions beaucoup des étudiants and des étudiants or mutiletatik asko and mutilak (in its existential

14 When existentially interpreted, the Basque definites DPs do not behave like usual indefinites and must always take narrow scope (pace the Ambiguity approach), just like BNs in English.

(i) a. \#Nere aitak bi sator hil ditu ordubetez. my father.erg two mole kill aux hour-for 'My father has killed two moles for an hour.'

b. Nere aitak satorr-ak hil ditu ordubetez. my father.erg mole-D.pl kill aux hour-for 'My father has killed moles for an hour.'

The sentence in (ia) can only be interpreted with the indefinite bi sator 'two moles' having wide scope over the atelic adverbial [bi sator $>$ adv.] and asserts that the same two moles have been killed again and again; a rather strange state of affairs. The sentence in (ib) on the other hand is completely grammatical. The reading we get is one where my father has killed different moles and the definite DP must necessarily take narrow scope below the adverbial [adv. > satorrak].

15 The reader is referred to Etxeberria $(2005,2008$, in prep) for an analysis of quantificational partitive constructions. 
interpretation) are distinguishable in that the former means 'being part of whatever the $\mathrm{N}$ denotes' while the meaning of the latter is 'being an instantiation of the kind denoted by the NP'. In fact, note that crosslinguistically, the behaviour of these two 'partitive constructions' is not the same. The 'being part of' is a quantificational partitive construction in every language, as the examples (42) show. On the other hand, the 'instantiation of a kind' is a bare plural in English and in Spanish (can also be so in Italian -see e.g. Longobardi, 1994; Chierchia, 1998b; Zamparelli, 2002a), it is a partitive construction in French (and it can also be so in Italian; not in English or in Spanish) and it is a definite DP in Basque (apparently, it can also be so in Italian -see Zamparelli, 2002a). So it seems as though the fact that the morphological realization of the two constructions is parallel in some Romance languages leads us to a misleading conclusion.

(42) a. English:

many of the students

b. Spanish: muchos de los estudiantes

c. French: beaucoup des étudiants

d. Italian: molto dei studenti

e. Basque: ikasleetatik asko

(43) a. English: students

b. Spanish: estudiantes

c. French: des étudiants

d. Italian: (dei) studenti

e. Basque: ikasleak

\section{Conclusions}

(i) Basque [-a] is a D and as such is always base-generated in [Head, DP] (as standardly assumed for the D cross-linguistically). Furthermore, [-a] is a D in all contexts (pace Artiagoitia, 2002), but very flexible in its ability to type-shift; the latter properly accounts for its range of different interpretations.

(ii) Although mass terms share the property of triggering singular verb agreement with singular count terms this paper postulates that they are number neutral (Delfitto \& Schroten, 1991; Doetjes, 1997; Dayal, 2004; Krifka, 2004). Thus, count terms are singular or plural while mass terms bear no number morphology at all.

(iii) The existential interpretation of Basque definites (in object position) depends on the kind-level reading. This provides further evidence for the NC approach (Chierchia, 1998b; Dayal, 2004; Zamparelli, 2002a).

(iv) Basque is typologically in between English and French: the former makes use of BNs to get existential interpretation while the latter needs the D plus the partitive preposition de to express the same meaning; in Basque, the $\mathrm{D}$ is there while the preposition is not. 
(v) The quantificational partitive constructions such as beaucoup des étudiants and the simple partitive des étudiants are distinguishable in that former means 'being part of whatever the $\mathrm{N}$ denotes' while the meaning of the latter is 'being an instantiation of the kind denoted by the NP'. It's been provided evidence that in fact the crosslinguistic behaviour of these two 'partitives' is not the same.

\section{References}

Anderson, S. (1985) Inflectional morphology. In Language Typology and Syntactic Description Volume 3 (T. Shopen et al., editors), pp. 150-201. Cambridge: Cambridge University Press.

Artiagoitia, X. (1997) DP predicates in Basque. In University of Washington Working Papers on Linguistics 15 (A. Taff, editor), pp. 161-198. Washington: University of Washington.

Artiagoitia, X. (2002) The functional structure of Basque noun phrases. In Erramu Boneta: Festschrift for Rudolf P. G. de Rijk (X. Artiagoitia et al., editors), pp. 73 -90. Vitoria-Gasteiz: ASJU (EHU-UPV).

Artiagoitia, X. (2004) Izen-Sintagmaren birziklatzea: IS-tik izenaren inguruko funtzio-buruetara. In Euskal Gramatika XXI Mendearen Atarian: Arazo Zaharrak, Azterbide Berriak (P. Albizu \& B. Fernández editors), pp. 13-38. Vitoria-Gasteiz: Arabako Foru Aldundia-EHU.

Azkarate, M. \& Altuna, P. (2001) Euskal morfologiaren historia. Donostia: Elkar.

Bosque, I. (1996) El sustantivo sin determinación. Madrid: Visor.

Bosveld-de Smet, L. (1997) On mass and plural quantification. The case of French des/du-NPs. PhD dissertation: University of Groningen.

Carlson, G. (1977) Reference to kinds in English. PhD dissertation: UMass, Amherst.

Chierchia, G. (1995) Individual level predicates as inherent generics. In The generic book (G. Carlson et al., editors), pp. 176-223. Chicago: The University of Chicago Press.

Chierchia, G. (1998a) Plurality of mass nouns and the notion of 'semantic parameter'. In Events and Grammar (S. Rothstein, editor), pp. 53-103. Dordrecht: Kluwer.

Chierchia, G. (1998b) Reference to kinds across languages, Natural Language Semantics, 6, 339-405.

Coyos, B. (1999) Le parler basque souletin des Arbailles: Une approche de l'ergativité. Paris: L'Harmattan.

Dayal, V. (2004) Number marking and (in)definiteness in kind terms, Linguistics \& Philosophy, 27, 393-450.

Delfitto, D. \& Schroten, J. (1991) Bare plurals and the number affix in DP, Probus, 3.2, $155-186$.

Diesing, M. (1992) Indefinites. Cambridge, MA: MIT Press.

Dobrovie-Sorin, C. \& Laca, B. (2003) Les noms sans déterminant dana les langues romanes'. In Les Langues Romanes (D. Godard, editor), pp. 235-281. Paris: CNRS. 
Dobrovie-Sorin, C., Bleam, T. \& Espinal, M.T. (2006) Bare nouns, number and types of incorporation. In Non-definiteness and plurality (S. Vogeleer \& L. Tasmowski, editors), pp. 51-79. Amsterdam: John Benjamins, Linguistics Today.

Doetjes, J. (1997) Quantifiers and Selection. On the Distribution of Quantifying Expressions in French, Dutch and English. The Hague: Holland Academic Graphics.

Eguren, L. (2006) Non-canonical uses of the article in Basque. In Proceedings of the 32nd Annual Meeting of the Berkeley Linguistics Society (M. J. Hauser et al., editors). Berkeley Linguistics Society, Berkeley.

Eguren, L. (to appear) Predication markers in Basque. In Noun Phrases and Nominalizations in Basque: Syntax and Semantics (U. Etxeberria et al., editors). Amsterdam: John Benjamins.

Espinal, T. \& McNally, L. (2007) Bare singular nominals and incorporating verbs. In Proceedings of the 3rd Ereus Workshop (G. Kaiser \& M. Leonetti, editors), pp. 45-66. Universität Konstanz Arbeitspapier 122.

Etxeberria, U. (2005) Quantification and domain restriction in Basque. $\mathrm{PhD}$ dissertation: University of the Basque Country (UPV-EHU) \& HiTT.

Etxeberria, U. (2008) On quantification in Basque and on how some languages restrict their quantificational domain overtly. In Quantification: A crosslinguistic perspective (L. Matthewson, editor), pp. 225-276. London: Emerald.

Etxeberria, U. (2009) Contextually restricted quantification in Basque. In $Q P$ Structure, Nominalizations, and the Role of DP (A. Giannakidou \& M. Rathert, editors), pp. 76-107. Oxford: Oxford University Press. Oxford Studies in Theoretical Linguistics Series.

Etxeberria, U. (in prep) Nominal expressions in Basque. Manuscript: IKER-CNRS.

Etxeberria, U. \& Giannakidou, A. (2009) Contextual domain restriction across languages: Determiners, quantifiers, and the structure of QP. Manuscript: IKER-CNRS \& University of Chicago.

Euskaltzaindia. (1993) Euskal Gramatika Laburra: Perpaus Bakuna. Bilbo: Euskaltzaindia.

Gerstner, C. \& Krifka, M. (1993) Genericity. In Handbuch der Syntax (J. Jacobs et al., editors). Berlin: Walter de Gruyter.

Gillon, B. (1992) Towards a common semantics for English count and mass nouns, Linguistics \& Philosophy, 15, 597-640.

Goenaga, P. (1980) Gramatika Bideetan. Donostia: Erein.

Goenaga, P. (1991) Izen sintagmaren egituraz. In Memoriae L. Mitxelena Magistri Sacrum (J. Lakarra, editor), pp. 847-865. Donostia: EHU.

Heim, I. (1992) Semantics of definite and indefinite noun phrases. PhD dissertation: MIT.

Heyd, S. (2003) L'interprétation des syntagmes nominaux en 'des' et 'de' en position sujet et objet. Généricité, habitualité et incorporation sémantique. PhD dissertation: Université Strasbourg II - Marc Bloch.

Higgimbotham, J. (1994) Mass and count quantifiers, Linguistics \& Philosophy, 17, 447-479.

Hualde, J. I. (2003) Verbs. In A grammar of Basque (J. I. Hualde \& J. Ortiz de Urbina, editors), pp. 155-198. Berlin: Walter de Gruyter. 
Kamp, H. (1981) A theory of truth and semantic interpretation. In Formal methods in the study of language (J. Groenendijk. et al., editors), pp. 277-322. Amsterdam: Mathematisch Centrum.

Kleiber, G. (1990) L'article LE générique sur le mode massif. Genève-Paris: Droz.

Kratzer, A. (1995) Stage level and individual level predicates. In The generic book (G. Carlson et al., editors), pp. 125-175. Chicago: The University of Chicago Press.

Krifka, M. (2004) Bare NPs: kind-referring, indefinites, both, or neither?. In Empirical issues in formal syntax and semantics 5 (O. Bonami et al., editors), Paris: CNRS.

Krifka, M. et al. (1995) Genericity: an introduction. In The generic book (G. Carlson et al., editors), pp. 1-124. Chicago: The University of Chicago Press.

Laca, B. (1996) Acerca de la Semántica de los 'Plurales Escuetos' del Español. In El Sustantivo sin Determinación. La Ausencia de Determinante en la Lengua Española (I. Bosque, editor). Madrid: Visor.

Laka, I. (1993) Unergatives that assign ergative, unaccusative that assign accusative. In Papers on case and agreement (J. Bobaljik \& C. Phillips, editors), pp. 149-172. Cambridge, MA: MIT Working Papers in Linguistics.

Lewis, D. (1995) Adverbs of quantification. In Formal semantics of natural language (E. Keenan, editor). Cambridge: Cambridge University Press.

Link, G. (1983) The logical analysis of plurals and mass terms: A lattice theoretical approach. In Meaning, use, and interpretation of language (R. Bäuerle et al., editors), pp. 302-323. Berlin: Walter de Gruyter.

Longobardi, G. (1994) Reference and proper names: A theory of N-movement in syntax and logical form, Linguistic Inquiry, 25.4, 609-665.

Longobardi, G. (2000) The structure of DPs: Some principles, parameters and problems. In The handbook of contemporary syntactic theory (C. Collins \& $\mathrm{M}$. Baltin, editors), pp. 502-601. London: Blackwell.

Manterola, J. (2006) - $a$ euskal artikulu definituaren gainean zenbait ohar. In Studies in Basque and historical linguistics in memory of R.L. Trask (J. Lakarra \& J. I . Hualde, editors), pp. 651-676. Donostia: ASJU.

Matushansky, O. (2005) Iraqui head seeks arms: Are bare nouns created equal?. Paper presented at the Bare Workshop, Utrecht.

McNally, L. (1995) Bare plurals in Spanish are interpreted as properties. In Formal Grammar (G. Morrill \& R. Oehrle, editors), pp. 197-212. Barcelona: Polytechnic University of Catalonia.

Milsark, G. (1977) Existential sentences in English. New York: Garland.

Ortiz de Urbina, J. (1989) Parametes in the grammar of Basque. Dordrecht: Foris.

Pelletier, F. J. \& Schubert, L. K. (2002) Mass expressions. In Handbook of Philosophical Logic Vol. 10 (D. Gabbay \& F. Guenthner, editors), pp. 265-350. Dordrecht: Kluwer.

de Rijk, R. P. G. (1972) Studies in Basque syntax: Relative clauses. PhD dissertation: MIT.

Rodriguez, S. (2003) Euskal artikuluaren sintaxiaz. Manuscript: University of the Basque Country.

Roodenberg, J. (2004) French bare arguments are not extinct: the case of coordinated bare noun, Linguistic Inquiry, 35.2, 301-313.

Ticio, E. (1996) El morfema $-a$ en vasco como marca de referencialidad, Interlinguistica VI. AJL. 
Trask, L. (2003) The noun phrase: nouns, determiners, and modifiers; pronouns and names. In A grammar of Basque (J.I. Hualde \& J. Ortiz de Urbina, editors), pp. 92 -134. Dordrecht: Kluwer.

Wilkinson, K. (1991) Studies in the semantics of generic noun phrases. $\mathrm{PhD}$ dissertation: UMass.

Zabala, I. (1993) Predikazioaren teoriak gramatika sortzailean. PhD dissertation: University of the Basque Country.

Zabala, I. (2003) Nominal predication: copulative sentences and secondary predication. In A grammar of Basque (J.I. Hualde \& J. Ortiz de Urbina, editors), pp. 324-339. Dordrecht: Kluwer.

Zamparelli, R. (2000) Layers in the Determiner Phrase. PhD dissertation: University of Rochester.

Zamparelli, R. (2002a) Definite and bare kind-denoting noun phrases. In Romance languages and linguistic theory 2000 (C. Beyssade et al., editors), pp. 305-342. Amsterdam: John Benjamins.

Zamparelli, R. (2002b) Dei ex machina: a note on plural/mass indefinite determiners Manuscript: Università di Bergamo.

Zwicky, A. (1985) Clitics and particles, Language, 61:2, 283-305.

Urtzi Etxeberria

IKER (CNRS-Bordeaux3-UPPA)

Gaztelu Berria, Paul Bert Plaza 15,

Errobiko Kanpusa

64100 Baiona, Basque Country, France

u.etxeberria@gmail.com 